MATEC Web of Conferences 6, 07001 (2013)

DOI: $10.1051 /$ matecconf/20130607001

(C) Owned by the authors, published by EDP Sciences, 2013

\title{
Thermal stability of different siliceous and calcareous aggregates subjected to high temperature
}

\author{
R. Niry R. 1,a , A.-L. Beaucour ${ }^{1}$, R. Hebert ${ }^{2}$, A. Noumowé ${ }^{1}$, B. Ledésert ${ }^{2}$ \\ and R. Bodet ${ }^{3}$ \\ ${ }^{1}$ Laboratoire de Mécanique et Matériaux du Génie Civil (L2MGC), Université de \\ Cergy-Pontoise, France \\ 2 Laboratoire Géosciences et Environnement de Cergy (GEC), Université de Cergy-Pontoise, \\ France \\ ${ }^{3}$ Union Nationale des Producteurs de Granulats (UNPG), Paris, France
}

\begin{abstract}
The goal of this study is to improve the knowledge of the deterioration of aggregates subject to high temperature phenomena and to characterise the physical and chemical transformations they undergo. Twenty one (21) aggregates of different mineralogical composition were exposed at temperatures up to $750^{\circ} \mathrm{C}$. The behaviour of siliceous and calcareous aggregates undergoing high temperature has been examined with respect to the evolution of physical, chemical and mineralogical properties.
\end{abstract}

\section{INTRODUCTION}

Aggregates constitute about $60 \%$ to $70 \%$ of the volume of concrete. This suggests that concrete properties are very likely influenced, if not dependant by those of the constituting aggregates. When a concrete structure is subject to high temperature as a building fire, it is required that people can leave safely before the structure's collapse. The single recommendation of the Part 1-2 of Eurocode 2 [1] concerning aggregates is a distinction between siliceous and calcareous aggregates.

The National Union of Aggregates Producer (UNPG) is a French professional organization that represents companies producing aggregates for building industry and public works. The aggregate's quality is a paramount criterion for concrete durability. Aggregate's quality is deteriorated by extraction processes in addition to the occurrence of original cracks or impurities due to rock geological heritage. The goal of this study is to improve the knowledge of aggregate's deterioration phenomena. The results will be useful to explain the aggregate's behaviour and their contribution to the concrete spalling during fire exposure.

\section{EXPERIMENTAL METHODOLOGY}

Petrographic analysis in order to classify the aggregates by rock origin is performed by macroscopic recognition, polarizing optical microscopy observation and X-ray diffraction (XRD). Physical properties like density and water porosity are determined. The aggregates were exposed to temperatures of 150 , 300, 500, 600 and $750^{\circ} \mathrm{C}$. Macroscopic and scanning electron microscope (SEM) observations were made at the end of each heating exposure. Cracking were analyzed with respect to the evolution

ae-mail: rniry-raz@u-cergy.fr

This is an Open Access article distributed under the terms of the Creative Commons Attribution License 2.0, which permits unrestricted use, distribution, and reproduction in any medium, provided the original work is properly cited. 


\section{MATEC Web of Conferences}

Table 1. Devices, parameters and specimen features for heat treatment.

\begin{tabular}{lll}
\hline \hline Devices & Parameters & Specimens \\
\hline Electric furnace (using & - Heating rate: $1{ }^{\circ} \mathrm{C} / \mathrm{min}$ & 10 to 20 aggregates about \\
Eurotherm heating program) & - Five $(5)$ steps of temperatures & $4 / 22.4 \mathrm{~mm}$ size \\
& with $1 \mathrm{~h}$ isotherm at 150,300, & \\
& 500,600 and $750{ }^{\circ} \mathrm{C}$ & \\
& - Cooling rate: $<1{ }^{\circ} \mathrm{C} / \mathrm{min}$ & \\
\hline TGA furnace (ref.: TA & - Heating and temperature & 10 to $20 \mathrm{mg}$ powder of \\
Instrument TGA Q50) & maintained $10 \mathrm{~min}$ at $30 \pm 5^{\circ} \mathrm{C}$ & aggregate (about $100 \mu \mathrm{m}$ \\
& - Heating rate: $10^{\circ} \mathrm{C} / \mathrm{min}$ up to & diameter), grinding is made \\
& $700^{\circ} \mathrm{C}$ & by a vibrating crusher \\
\hline Thermal expansion furnace & - Heating rate: $10^{\circ} \mathrm{C} / \mathrm{min}$ up to & Parallelepiped samples of \\
(ref.: Netzsch model 402 C & $750{ }^{\circ} \mathrm{C}$ & $16 \varnothing \times 20$ mm in length \\
Pushrod dilatometer) & $-10 \mathrm{~min}$ isotherm at $750{ }^{\circ} \mathrm{C}$ & \\
\hline
\end{tabular}

of crystalline phases (XRD), thermal expansion, final weight loss and transient weight loss by thermogravimetric analysis (TGA analyses).

Ten to twenty (10 to 20 ) specimens are selected per type of aggregate for all the tests. They are washed until clear water and dried at $65^{\circ} \mathrm{C}$ during 48 hours at least (until complete drying: no weight variation) before preparation if there is any (grinding and carving). Three (3) devices are used for heat treatment: electric furnace, thermogravimetric analysis furnace and thermal expansion furnace. Parameters and specimens preparation are summed up in Table 1.

\section{MINERALOGICAL AND PHYSICAL PROPERTIES}

\subsection{Petrographic study}

A petrographic recognition (Table 2) is realized in order to identify the different rock facies composing the aggregates according to European Standards NF EN 932-1 [2] and NF EN 932-3 [3]. Firstly, facies are selected visually by their colour, origin (sedimentary, magmatic, metamorphic), granular texture (coarse or fine grained). Secondly, in addition with visual recognition, thin sections are observed under polarizing microscope in order to complete and confirm the rock classification. Finally, X-Ray diffraction analysis completes the mineralogical identification (described in paragraph 3.2).

Twenty one (21) aggregates of different petrographies coming from 10 different quarries were selected. Figure 1 shows rock categories:

- Igneous rocks: granites, basalts and rhyolite;

- Sedimentary rocks: limestones and flints;

- a third categories corresponding to igneous or sedimentary rocks: quartz vein or quartzite, quartzofeldspathic rock.

\subsection{Mineralogical composition by X-Ray diffraction analysis (XRD)}

Aggregates from quartzo-feldspathic rock (1QS, 1QF) contain quartz and may be amorphous variety of iron $(\mathrm{Fe})$ causing Hematite $\left(\mathrm{Fe}_{2} \mathrm{O}_{3}\right)$ formation identified after heating/cooling up to $750{ }^{\circ} \mathrm{C}$. In sample $1 \mathrm{QS}$, the presence of Albite $\left(\mathrm{NaAlSi}_{3} \mathrm{O}_{8}\right.$ the sodic end-member of feldspars) is also reported. It should be noted that feldspar alteration produces clay minerals [4]. Clay minerals are identified within granite's aggregates $(2 \mathrm{G}, 8 \mathrm{G})$. Basalts $(9 \mathrm{BN}, 9 \mathrm{BV})$ contain chlorite minerals $(\mathrm{Fe}, \mathrm{Mg}, \mathrm{Al})_{6}(\mathrm{Si}, \mathrm{Al})_{4} \mathrm{O}_{10}(\mathrm{OH})_{8}$. Flint aggregates are composed of cryptocrystalline silica $\left(\mathrm{SiO}_{2}\right)$. 
Table 2. Petrograaphic classification of differents facies.

\begin{tabular}{|c|c|c|c|c|c|}
\hline \multirow{2}{*}{\multicolumn{2}{|c|}{$\mathrm{N}^{\circ}$ Quaries }} & \multicolumn{4}{|c|}{ Facies } \\
\hline & & Main & Réf. & Description & Quota [\%] \\
\hline \multirow[t]{5}{*}{1} & \multirow{5}{*}{ Siliceous of Loire } & Quartzite or & $1 \mathrm{~A}$ & Honeycomb quartz vein & 20 \\
\hline & & quartz vein & $1 \mathrm{M}$ & Massive quartz vein & 10 \\
\hline & & Quartzo- & $1 \mathrm{QF}$ & Quartzo-feldspar vein & 30 \\
\hline & & feldspathic rock & $1 Q S$ & Sedimentary quartzo-feldspar & 10 \\
\hline & & Flint & $1 \mathrm{~S}$ & Brown flint & 30 \\
\hline \multirow[t]{2}{*}{2} & \multirow[t]{2}{*}{ Siliceous of Moselle } & $\begin{array}{l}\text { Quartzite or } \\
\text { quartz vein }\end{array}$ & $2 Q$ & $\begin{array}{l}\text { Massive quartz vein or quart } \\
\text { zite }\end{array}$ & 25 \\
\hline & & Granite & $2 \mathrm{G}$ & Pink granite & 75 \\
\hline 3 & Limestone of Tournaisis & Limestone & $3 \mathrm{C}$ & Black limestone & 100 \\
\hline \multirow[t]{2}{*}{4} & & & $4 \mathrm{R}$ & Coarse texture & 25 \\
\hline & Limestone of Marseille & Limestone & $4 \mathrm{~L}$ & Fine grained texture & 75 \\
\hline \multirow[t]{3}{*}{5} & & Oolithic & 50 & Beige oolithic limestone & 32 \\
\hline & Limestone of Champagne & Lithographic & $5 \mathrm{LB}$ & Beige lithographic limestone & 33 \\
\hline & & & $5 \mathrm{LG}$ & Grey lithographic limestone & 35 \\
\hline \multirow[t]{3}{*}{6} & Flint of Baie de Somme & Flints & $6 \mathrm{~N}$ & Black flint & 25 \\
\hline & & & $6 \mathrm{M}$ & Brown flint & 40 \\
\hline & & & $6 \mathrm{G}$ & Grey flint & 35 \\
\hline 7 & Chailles flint & Flint & $7 \mathrm{~S}$ & Brown flint & 100 \\
\hline 8 & Granite & Granite & $8 \mathrm{G}$ & Red granite & 100 \\
\hline \multirow[t]{2}{*}{9} & Basalt & Basalt & 9BV & Green basalt & 37 \\
\hline & & & $9 \mathrm{BN}$ & Black basalt & 63 \\
\hline 10 & Rhyolite & Rhyolite & $10 \mathrm{R}$ & Blue rhyolite & 100 \\
\hline
\end{tabular}

For calcareous aggregates, limestone of Tournaisis (3C) is composed of calcite with minor amount of quartz (about 9-13\%). Indeed, quartz has been observed in thin sections. It is also the case for Limestone of Champagne (5LB, 5LG, 5O) (1.2\% of silica). Marseille carbonates (4R and 4L) are dolomitic $\left((\mathrm{Ca} ; \mathrm{Mg})\left(\mathrm{CO}_{3}\right)_{2}\right)$ with about $18-20 \%$ of magnesium oxide for $33-55 \%$ of calcium oxide and less than $1 \%$ of silica.

\subsection{Physical properties: Density and porosity}

These physical properties are measured according to the European Standards NF EN 1936 [5]. The two granites $(2 \mathrm{G}, 8 \mathrm{G})$ can be distinguished on the basis of their density and porosity: the lower the density, the higher the porosity. Basalt aggregates show the highest density, the green basalt (9BV) being the denser. Both of the basalts aggregates show a strong alteration characterized by the presence of secondary chlorite. The green colour of basalt 9BV is probably due to a significant amount of chlorite. Limestone of Tournaisis (3C) is the denser and less porous limestone compared to the others. The oolitic facies $(5 \mathrm{O})$ is the less dense and more porous in the limestones of Champagne. Flint aggregates present various densities but they show porosity values similar to quartzites or quartz vein. Sedimentary quartzo-feldspathic rock (1QS) differs from quartzo-feldspathic vein (1QF) by its poor density and important porosity. Note that $1 \mathrm{QS}$ aggregates are so various in terms of their aspect which explain standard deviation disparity. 


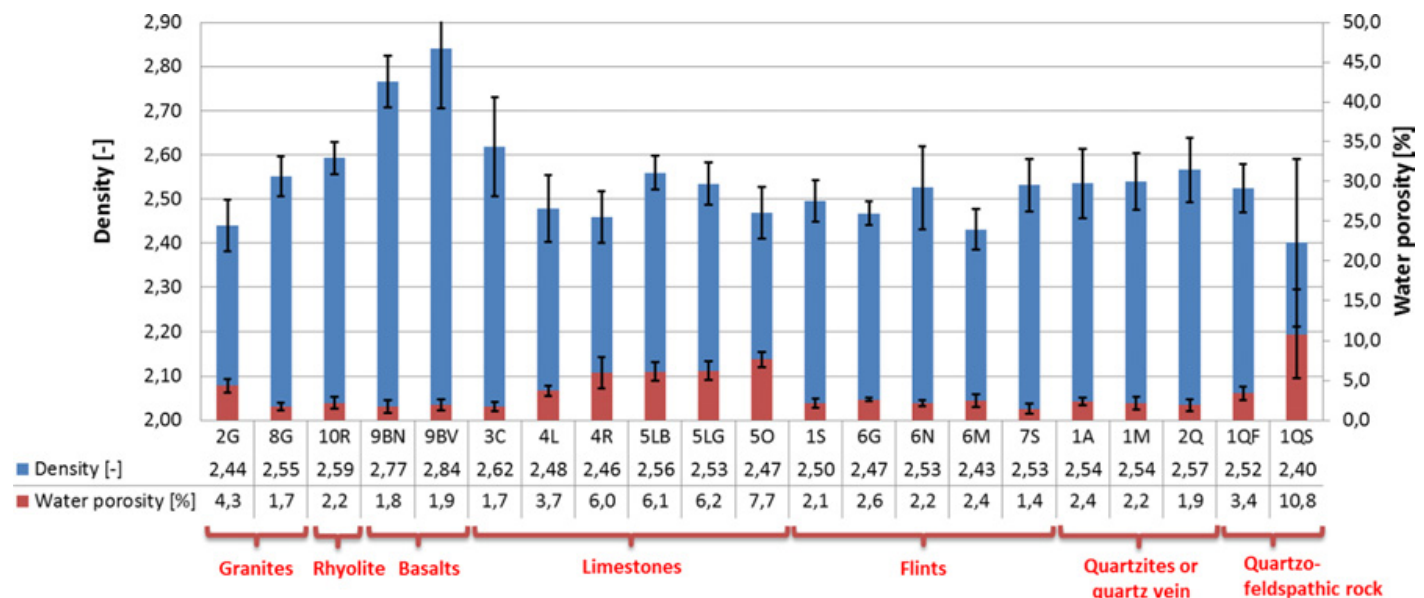

Figure 1. Density and water porosity.

\section{DISCUSSION AND INTERPRETATION ON THERMAL BEHAVIOUR}

Before all the thermal tests, specimens are dried at $65^{\circ} \mathrm{C}$ until 48 hours at least (no weight variation) (see paragraph 2).

\subsection{Macroscopic observations}

Flint aggregates are subjected to splitting phenomena which happen from $300{ }^{\circ} \mathrm{C}$. This might be caused by water pressure inside of micropores and the presence of silanols $\left(\mathrm{SiO}_{5-2} \mathrm{H}\right)$ inside the crystalline structure of the aggregate itself [6-8]. Xing [6] showed that initial moisture condition has an influence on the thermal stability of flints: spalling temperature is higher for dried aggregates than for saturated aggregates.

From $300^{\circ} \mathrm{C}$ and higher, the core of flints aggregates whitens probably due to a gradient temperature: whitening progresses from core to the rim (Fig. 2). Otherwise, a structural change must happen because aggregates sound like bells which suggests an increase of the internal porosity [6]. This phenomenon may be the result of reactions affecting trapped impurities. Flint is made of cryptocrystalline varieties of silica. It is composed of chalcedony which is a group name used for describing compact varieties of silica composed of minute crystals of quartz with submicroscopic pores [4]. Flint formingphases may contain fluid inclusions (observed in thin section) instead of quartzite or quartz vein structure.

Splitting phenomenon is also observed on basalt aggregates during heating at $750{ }^{\circ} \mathrm{C}$. Figure 3 shows one of these aggregates (the one in the center of the picture). SEM observations show that fragmented surfaces exhibit an array of micropores. Assuming that the micropores contain water, the pore vapour pressure could have resulted in the spalling of these aggregates. The presence of hydrated silicates such as chlorite is a possible source of water. Another possibility is that basalt may contain trapped gas vapour within vesicles during its formation. Splitting effect by excessive pressure may occur when temperature increases [9]. The assumption that planes of crystal lattice can break under aggregates' expansion can also be raised. In fact, share split surfaces of aggregates are nearly flat.

From $300^{\circ} \mathrm{C}$, quartzo-feldspathic rock (1QF and $1 \mathrm{QS}$ ) turn into red (Fig. 4). Quartz and granite blush slightly and contrast colour of rhyolite increases. These aggregates are stable and do not show any macroscopic structural failure up to $750^{\circ} \mathrm{C}$. Goethite $\mathrm{FeO}(\mathrm{OH})$ is a mineral which dehydrates and 


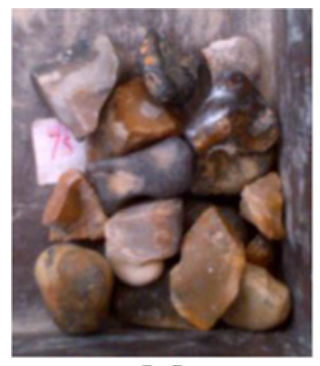

[a]

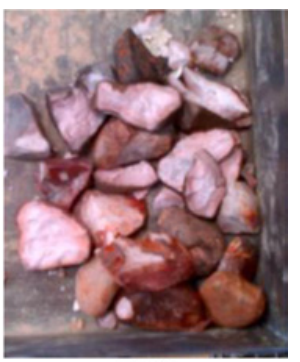

[b]

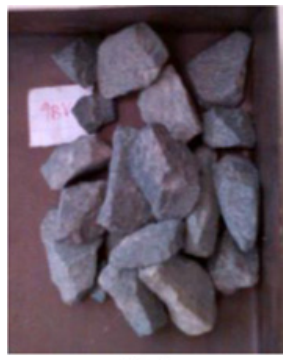

[a]

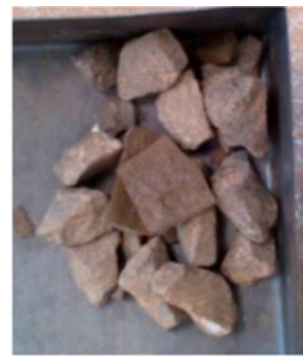

[b]

Figure 2. Chailles flint (7S).

Figure 3. Green basalt (9BV).

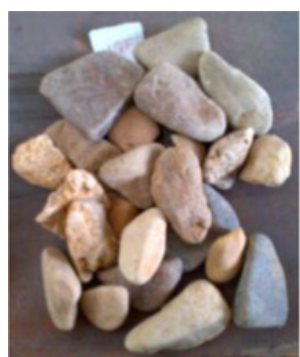

[a]

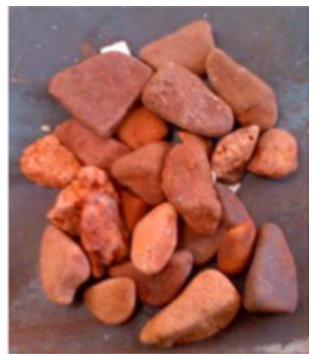

[b]

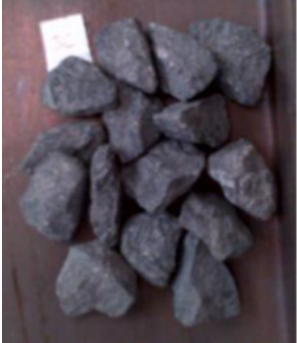

[a]

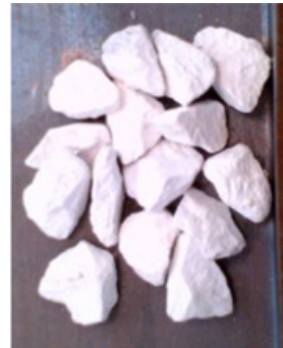

[b]

Figure 4. Quartzo-feldspathic vein (1QF) [a]: initial appearance [b]: after $750^{\circ} \mathrm{C}$ heating/cooling appearance.

Figure 5. Limestone of Tournaisis (3C).

produces hematite $\mathrm{Fe}_{2} \mathrm{O}_{3}$ at $250{ }^{\circ} \mathrm{C}$ responsible of the red colour after heating $[10,11]$. It should be noted that red colour is observed from $300^{\circ} \mathrm{C}$.

Limestone aggregates are subject to the decarbonation phenomena after heating at $600{ }^{\circ} \mathrm{C}$. After cooling, they are wrapped by a thick white layer of portlandite $\left(\mathrm{Ca}(\mathrm{OH})_{2}\right)$ or brucite $\left(\mathrm{Mg}(\mathrm{OH})_{2}\right)$ which crumbles when touched (Fig. 5).

\subsection{Micro-cracking investigation by scanning electron microscopy (SEM)}

Flint aggregates present an evolution of micro-cracks from $500{ }^{\circ} \mathrm{C}$ to $750{ }^{\circ} \mathrm{C}$ as presented in Figure 6 . It is possible to classify the aggregates by the occurrence of micro-cracks:

- No significant cracks (due or not to thermal constraints) is observed up to $600{ }^{\circ} \mathrm{C}$ for calcareous aggregates, quartz (expect $1 \mathrm{~A}$ certainly because of its honeycomb structure, see Table 2) and quartzo-feldspathic vein (1QF);

- Small-scale cracks are observed in basalts (9BN, 9BV), rhyolite (10R), granites (2G, 8G) and sedimentary quartzo-feldspathic rock (1QS);

- Widespread development of cracks observed in flints (Fig. 6).

\subsection{Thermal expansion}

Figure 7 and Figure 8 show the thermal expansion of siliceous aggregates and calcareous aggregates. 


\section{MATEC Web of Conferences}
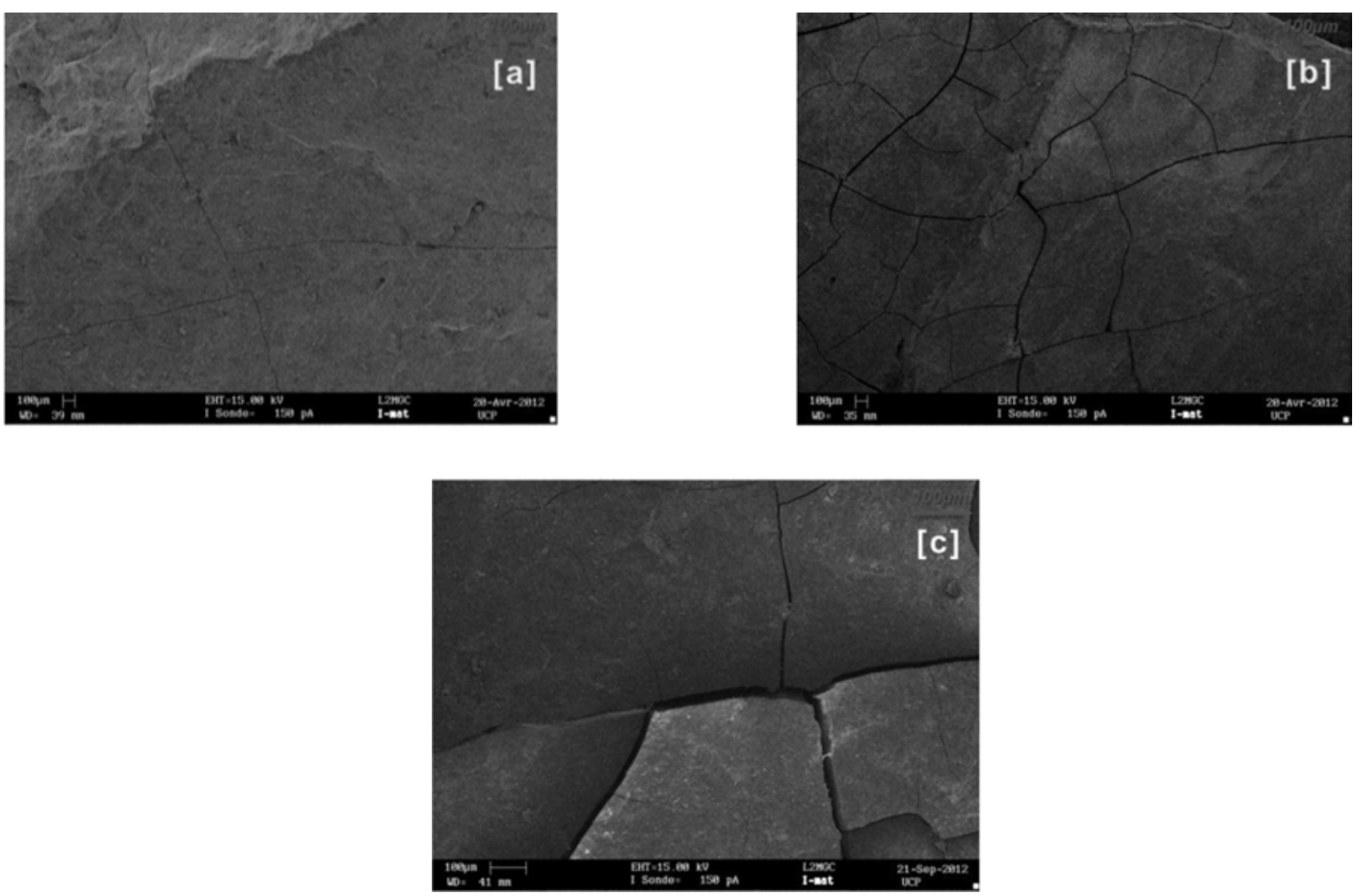

Figure 6. Flint's cracking by SEM as function of temperature. -[a]: after heating/cooling at $500{ }^{\circ} \mathrm{C}$ : primary cracking develops, cracks meet at right angles; - [b]: after heating/cooling at $600{ }^{\circ} \mathrm{C}$ : secondary orthogonal cracking develops dividing the flint surface into spalled blocks; - [c]: after heating/cooling at $750{ }^{\circ} \mathrm{C}$ : spalled blocks are subdivided by tertiary cracking.

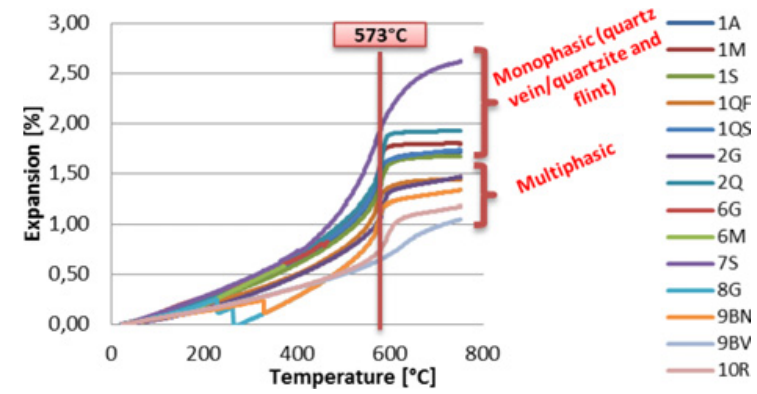

Figure 7. Siliceous aggregates expansion.

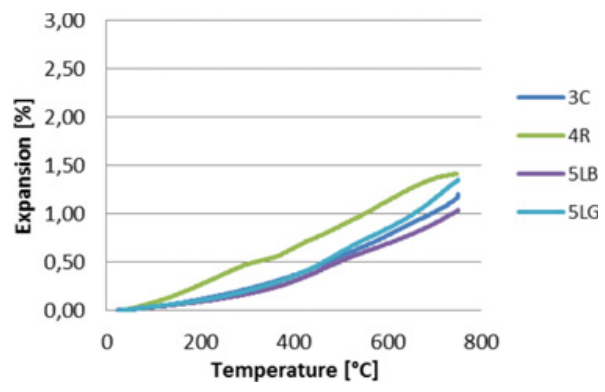

Figure 8. Limestone aggregates expansion.

The thermal expansion exhibits three (3) categories of aggregates:

- Monophasic siliceous aggregates gather quartz and flint: this category of aggregate mainly contains quartz or silica polymorphs. They represent the most expanded aggregates because of the allotropic quartz $\alpha-\beta$ transformation at $573^{\circ} \mathrm{C}$. The more quartz content, the more expansion.

- Multiphasic siliceous aggregates gather quartzo-feldspathic rocks, granites, basalts and rhyolite: as opposed to monophasic siliceous aggregates, this category contains other minerals in addition to quartz. Accordingly, they expand less than monophasic quartz aggregates. 


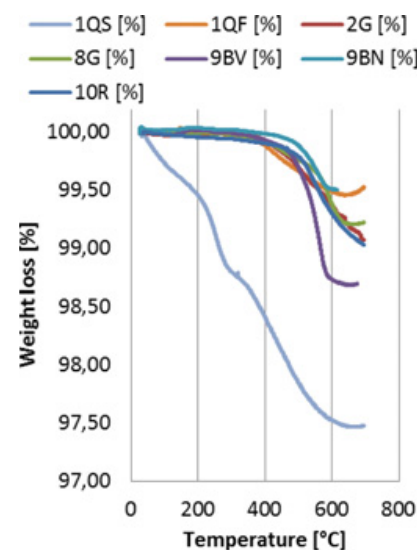

Figure 9. Weight loss (by TGA) of multiphasic siliceous aggregates.

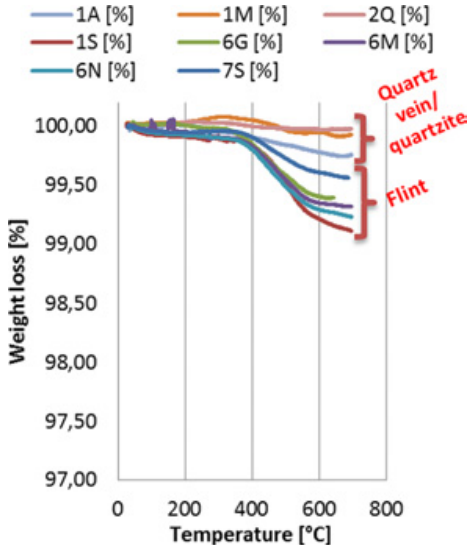

Figure 10. Weight loss (by TGA) of monophasic siliceous aggregates.

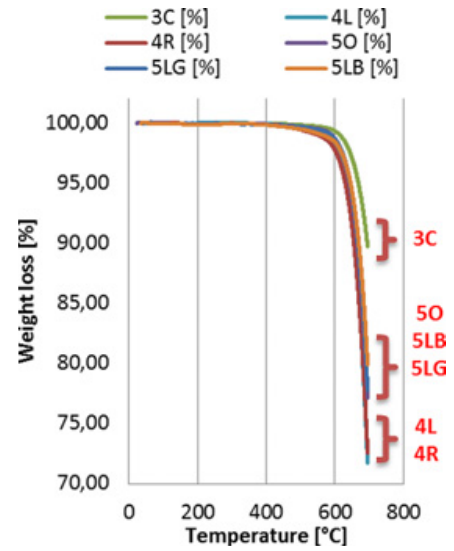

Figure 11. Weight loss (by TGA) of limestone aggregate.

- Calcareous aggregates: a thermal expansion rate variation due to relaxation phenomenon happens at around $300-400^{\circ} \mathrm{C}$. Another one happens at around $500-600^{\circ} \mathrm{C}$ probably corresponding to the beginning of the decarbonation and influenced by quartz transformation.

Final expansion for multiphasic siliceous aggregates which do not expand much more than calcareous aggregates does not exceed $1.5 \%$ at $750^{\circ} \mathrm{C}$. Expecting that multiphasic siliceous aggregates expansion rate increase from $450^{\circ} \mathrm{C}$ to $580^{\circ} \mathrm{C}$ due to quartz $\alpha-\beta$ transformation [12]. At around $350^{\circ} \mathrm{C}$, calcareous aggregates' thermal expansion seems to increase. A discontinuity of the rate of expansion is observed and happens also at around $550^{\circ} \mathrm{C}$. At lower temperature (below $300^{\circ} \mathrm{C}$ ), siliceous thermal expansion is generally more important than calcareous' one [13].

\subsection{Thermogravimetric Analysis (TGA)}

Weight loss is more important for flints than for quartz vein/quartzite among monophasic aggregates. It can be explain by the presence of silanols and trapped water inside flint's microstructure $[6,8]$. Furthermore, similar weight losses between multiphasic and flints aggregates can be noted: all losses about $0.5-1 \%$ expect samples $9 \mathrm{BV}$ and $1 \mathrm{QS}$. For sedimentary quartzo-feldspathic aggregates (1QS), the hematite production reported by XRD analysis may come from an amorphous variety of iron oxide $(\mathrm{FeO})$, or hydrated iron oxide such as goethite $(\mathrm{FeO}(\mathrm{OH}))$. [14]. Therewith, the presence of albite which may be altered and then producing clay minerals can explain why this aggregate shows a strong weight loss. Dehydration of chlorite happening at about $500^{\circ} \mathrm{C}$ in green basalt (9BV) may also explain the more important thermal weight loss compared to black basalt (9BN).

As shown in Figure 11 by TGA and with respect with XRD analysis and physical properties, the variation in the limestone aggregate composition (see paragraph 3.2) may affect the weight loss up to $750{ }^{\circ} \mathrm{C}$ : limestone of Tournaisis (3C) loses about $10 \mathrm{wt} \%$, limestone of Champagne (5O, 5LB, 5LG) about $20 \mathrm{wt} \%$ and limestone of Marseille (4R and $4 \mathrm{~L}$ ) about $25 \mathrm{wt} \%$. Dolomite $\left(\mathrm{CaMg}\left(\mathrm{CO}_{3}\right)_{2}\right)$ present in limestone of Marseille is fully decomposed after heating up to $750{ }^{\circ} \mathrm{C}$. As limestone of Tournaisis $(3 \mathrm{C})$ is the less porous among limestone aggregates, weight loss may also correlate with initial porosity. 


\section{MATEC Web of Conferences}

\section{CONCLUSION AND PERSPECTIVE}

The main parameters controlling the high temperature behaviour of aggregates have been identified: chemical and mineralogical composition associated with granular texture and crystallinity of quartz trapped water and silica hydrates content which may increase the internal pore pressure under high temperature - porosity combined with cracks evolution.

Up to $600^{\circ} \mathrm{C}$, limestone aggregates exhibit the best thermal structural stability. Limestone aggregates ( $4 \mathrm{R}$ and $5 \mathrm{O}$ after $500^{\circ} \mathrm{C}$ ), quartz vein/quartzite and quartzo-feldspathic rock did not show any evidence of micro-crack before $500^{\circ} \mathrm{C}$. The other rocks (basalts, rhyolite and granites) displayed short length micro-cracks, except flints that cracked intensively. In flints, the density and opening of cracks increase with the temperature from $300^{\circ} \mathrm{C}$. The quartz content affects thermal expansion for siliceous aggregates. Impurities and altered minerals affect physical properties and thermal stability especially if it contains hydrated products. Calcite/magnesium and quartz content affect thermal weight loss for calcareous aggregates. The single distinction of siliceous and calcareous aggregates does not allow to predict the thermal stability of aggregates at high temperature.

This study was conducted to improve our understanding of concrete thermal behaviour. Based on these results, some aggregates were selected to formulate concretes. Research works are now carried out to study the impact of mineralogical properties of aggregates on the concrete behaviour under high temperature.

Acknowledgment goes to UNPG for it financial support and implication. This work was carried out with Annelise Cousture and Lilian Cristofol, technical team of L2MGC. Acknowledgment for the participation of LPPI ${ }^{1}$ of University of Cergy-Pontoise - France.

\section{References}

[1] CEN, "NF EN 1992-1-2 : Calcul des structures en béton,” in Partie 1-2 : Règles générales - Calcul du comportement au feu, ed. Bruxelles, 2004.

[2] CEN, "NF EN 932-1 : Essais pour déterminer les propriétés générales des granulats," in Partie 1 : Méthodes d'échantillonage, ed. Bruxelles, Décembre 1996.

[3] CEN, "NF EN 932-3 : Essais pour déterminer les propirétés générales des granulats," in Partie 3 : Procédure et terminologie pour la description pétrographique simplifiée, ed. Bruxelles, Décembre 1996.

[4] W. A. Deer, R. A. Howie, and J. Zussman, An introduction to the rock-forming minerals, British Library Cataloguing in Publication Data ed.: Pearson Education Limited, 1996.

[5] CEN, "NF EN 1936 : Méthodes d'essai des pierres naturelles - Détermination des masses volumiques réelle et apparente et des porosités ouverte et totale," ed. Bruxelles, 2007.

[6] Z. Xing, A. L. Beaucour, R. Hebert, A. Noumowe, and B. Ledesert, "Influence of the nature of aggregates on the behaviour of concrete subjected to elevated temperature," Cement and Concrete Research, vol. 41, pp. 392-402, Apr 2011.

[7] J. Verstraete, "Approche multi-technique et multi-échelle d'étude des propriétés structurales des matériaux hétérogènes : application à un granulat siliceux naturel," Laboratoire Analyse Physique du Centre de Recherche de l'Ecole des Mines de Douai, Thèse de Doctorat de l'université de Haute-Alsace, Mulhouse, 2005.

\footnotetext{
${ }^{1}$ Laboratoire de Physico-chimie des Polymères et des Interfaces.
} 


\section{IWCS 2013}

[8] E. F. Vansant, P. Van Der Voort, and K. C. Vrancken, Characterization and Chemical Modification of the Silica Surface: Elsevier Science, 1995.

[9] F. Robert, H. Colina, and G. Debicki, "La durabilité des bétons face aux incendies," in $L a$ durabilité des bétons, J.-P. Ollivier and A. Vichot, Eds., ed France: Presse des Ponts et Chaussées, 2008.

[10] F. Homand-Etienne, "Comportement mécanique des roches en fonction de la température," Mémoire $n^{\circ} 46$, Sciences de la terre, Fondation scientifique de la géologie et de ses applications, 1986.

[11] J. P. Ingham, "Application of petrographic examination techniques to the assessment of firedamaged concrete and masonry structures," Materials Characterization, vol. 60, pp. 700-709, 7// 2009.

[12] H. Grimm and B. Dorner, "On the mechanism of the $\alpha-\beta$ phase transformation of quartz," Journal of Physics and Chemistry of Solids, vol. 36, pp. 407-413, 1975.

[13] F. Robert and H. Colina, "The influence of aggregates on the mechanical characteristics of concrete exposed to fire," Magazine of Concrete Research, vol. 61, p. 11, 2009.

[14] R. M. Cornell and U. Schwertmann, The iron oxides: structure, properties, reactions, occurrences and uses: Wiley-Vch, 2003. 